\title{
Between formality and effectiveness: The dynamics of social participation in the political cycle of a tourism management council in Juiz de Fora/MG *
}

\author{
Thiago Duarte Pimentel*, Fabíola Cristina Costa De Carvalho, Marcela Costa Bifano De Oliveira, Eliza Feres De Lima
} Moura

Keywords:

Public Management

Councils,

Social Participation,

Political Cycle, Policy,

Tourism,

Brazil.

Article History:

Submitted:18.03.2019

Accepted: 16.08.2020

\section{ABSTRACT}

This paper aims to analyze the process of perceiving a problem and the generation of proposals to be implemented by members of the Municipal Tourism Council (COMTUR) of Juiz de For a in Minas Gerais/Brazil from 2011 to 2015. The theoretical lenses are based on public management and tourism, focusing on the mechanisms and processes of social participation. It was allowed (1) to identify the frequency of Board members, (2) to qualificate their participation, (3) as well as to analyze the main results of the proposals converted into concrete actions. Methodologically, this study used documentary analysis of minutes of meetings, institutional and other public official documents, as well as unofficial ones, such as press releases, reports and interviews. The data were ordered, classified and analyzed through content analysis in order to quantify the frequencies and thematic categories. The results show that, mostly, there is a low level of attendance (what was called "nominal participation") or even abstention at the meetings. This was even most restricted when it was analysed the effectiveness of participation, which means that the attendants were active in the discussions, giving more elaborated ideas and trying to implement them. In this sense, only three actors had a qualified participation, through which proposals are generated. Yet, only a fraction of proposals were converted into results. Therefore, it was concluded that there is an institutional fragility and a crisis of legitimacy of this mechanism (Council), given the minority expression of those who participate, whether nominally or in a qualified way.

\section{Introduction}

In recent years, councils have become synonymous with democratic and participatory management (Paes de Paula, 2008)1, especially in accordance with common sense. This logic underlies the thesis that in appropriate spaces, free from coercion (imposed or self-imposed), social actors could express themselves in a more authentic and trustworthy way, and make their local interests and ideas to be asserted (Tenório, 2008). So that, the various actors that take part in the management councils, have the possibility to express themselves, formulate, monitor and control public policies, supposedly exercising greater control over the State (Gohn, 2011; IPEA, 2012).

In Brazil, since the redemocration period, this kind of mechanism, inspired by the direct participation, has been incorporated in the Constitution (Brazil, 1988). Its use has increasingly spread throughout the country and became institutionalized in various instances, at the three levels of the State,

\begin{tabular}{|c|c|}
\hline *Corresponding Author & Research Paper \\
\hline Thiago Duarte Pimentel: & $\begin{array}{l}\text { Prof., Universidade Federal de Juiz de Fora, Minas Gerais, Brazil, Email: thiago.pimentel@ufjf.edu.br, } \\
\text { Orcid Id:0000-0003-1889-069X }\end{array}$ \\
\hline Fabíola Cristina Costa De Carvalho: & $\begin{array}{l}\text { Independent Resercher, Universidade Federal de Juiz de Fora, Minas Gerais, Brazil, Email: } \\
\text { fabiolacarvalho.tur@hotmail.com Orcid Id:0000-0001-5719-9020 }\end{array}$ \\
\hline Marcela Costa Bifano De Oliveira: & $\begin{array}{l}\text { Ph.D Student, Universidad de Guadalajara - Centro Universitario de la Costa, Mexico, Email: } \\
\text { marbifano@gmail.com, Orcid Id: 0000-0002-8102-5247 }\end{array}$ \\
\hline : & $\begin{array}{l}\text { Master of Science, Universidade Federal de Juiz de Fora, Minas Gerais, } \quad \text { Brazil, Email: } \\
\text { elizaferes@gmail.com, Orcid Id:0000-0001-7663-6230 }\end{array}$ \\
\hline
\end{tabular}

\section{(c) (i) $\odot \ominus$}

${ }^{+}$Acknowledgement: Previous versions of this paper were presented and published, in Portuguese, at the IX Latin American Congress on Political Science, organized by the Latin American Association of Political Sciene (Asociación Latinoamericana de Ciencia Politica - ALACIP), and the Interdisciplinary Journal of Social Management (Revista Interdisciplinar de Gestão Social), see Pimentel et al. (2019). 
and even in private organizations. According to Gohn (2011, p. 354)2:

\begin{abstract}
Management councils are new instruments of expression representation and participation. In theory, they have the potential for political transformation. If effectively representative, they can give a new format to social policies, since they deal with the process of policy formation and decision making. With the councils, a new public institution is generated, since they create a new social-public or nonstate public sphere. This is a new pattern of relations between the State and society because they make it possible for social segments to participate in the formulation of social policies and give the population access to the spaces in which political decisions are made.
\end{abstract}

However, despite their possible contributions, in several situations, these mechanisms have shown questionable results (Abramovay, 2001). The symbolic use of councils, as a formal mechanism to qualify the public management (on municipal, state or federal level) according to legislation requirements, has continuously been verified. Alternatively, when the Councils become institutionalized, they convert in state apparatuses, "with the same vicissitudes of the other institutions of political power" (Gurgel \& Justen, 2013, p. 375). In addition, there are rare occasions when the (fragile) assumption is made that, on the basis of this mechanism, the actors would participate more and more effectively (Kliksberg, 1999). On the contrary, criticisms accusing of ignorance, lack of interest and issues about the relevance and applicability of these structures combine with the perception of these structures as slow, unspecific, inconclusive and not very pragmatic (Nobrega, \& Figueiredo, 2014). All this has led to the questioning of management boards per se [themselves] as instruments of empowerment and social control (Mata, 2016).

\footnotetext{
In municipalities without an organizational-associative tradition councils have been only a legal-formal reality and often an extra instruction in the hands of the mayor and the elites, who speak on behalf of the community, as its official representatives, not at al meeting the objectives of being mechanisms of control and inspection of public affairs (Gonh, 2011, p. 355).
}

In this sense, a fundamental question is to be asked: how collective are the results and the process of participation in institutionalized spaces for "social participation", such as councils? Or to put it another way - and starting from the principle of methodical doubt -, is there a possibility that the spaces of social participation will avoid or be reduced to the control of a minority?

We start from the assumption that, although from the formal point of view, there is supposed to be the possibility of a democratic and pluralist representation , concretely the representation ${ }^{3}$ and participation of the actors are guided by material, ideological and conjectural elements, which manifest themselves in specific situations, according to the degree of restrictions or openness faced to their placements and possibilities to speak out. Additionally, we assume that the social position of the agent tends to affect its capacity of participation and, consequently, its influence in the process.

In addition, the discussion arises on the fact that the diversification of interests represented in these spaces leads to the (un)balance of ideas, and that the participation normally existing does not materialize in a democratic dynamic, in the sense of the existence of diversity of representation of themes and interests as characterized by the social demands of each place.

Many researches ${ }^{4}$, in the field of public policies, have been dedicated attention to the structures of councils, their formal aspects, their functioning, as well as the assumptions and conditions that underpin them, including the behavior of members. However, studies on the type of participation still need to be discussed, particularly what we call "qualified" (or active) participation in its aspects and results within the interactive dynamics of social participation within the Council, since this type of participation enables them to act effectively, playing roles and functions within the political cycle, considering the context of local public agendas, and this, therefore, is the theoretical contribution of this work. On the other hand, from an empirical or pragmatic point of view, this work shows that only the formal institutionalization of such participation mechanisms seems unable to ensure the effective fulfillment of its teleology. This may suggest the absence of a real civil sphere (Alexander, 2007).

Based on the classical theory of public policy, we seek to analyse the public policy cycle, and its

\footnotetext{
${ }^{2}$ In fact, management (or administrative) councils, in private companies, emerge as one of the mechanisms for resolving the "agency conflict" - in the context of the governance literature that will move from the private to the public sector in the early 1970's and beyond - a concept that has gradually been absorbed into the public area, based on the thesis of the inclusion of several controllers in the process of management. In this way, that process would be more, anonymously and diffusely, controlled, like a kind of social panoptism.

${ }^{3}$ Assuming here, only by way of hypothetical reasoning, that the thesis of political pluralism is adequate. Political pluralism is the vision that society is composed of several groups, competing among themselves, which seek to limit any hegemonic, particularly that of the State (Bobbio et al., 2004).

${ }^{4}$ See, for example, regarding the national literature on public councils management: Tatagiba (2005), Almeida (2009), Oliveira, Pereira \& Oliveira (2010), Martins, Ckagnazaroff, \& Lage (2012), Gurgel \& Justen (2013); this topic on tourism, see: Massukado-Nakatani \& Teixeira (2009); Araujo \& Cesar (2012), Araujo (2014), Frade Da Mata \& Emmendoerfer, M. L. (2017); and the international literature on tourism, see: Augustyn \& Knowles (2000), Dredge, Dianne. (2004), Beaumont \& Dredge (2009), Zapata \& Hall (2012), Velasco (2016), Paddison \& Walmsley (2018).
} 
correlated main concepts: policy arena and policy issue; regarding the empirical case of the Tourism Municipal Council of Juiz de Fora (COMTURJF), in Brazil. Specifically, this paper shows how individual actors interact in order to push (or avoid) touristic issues in the public arena and what themes introduced in their agenda are converted into actions to be carried out among the group.

The relevance of the research lies precisely in the fact that the knowledge of the public sphere of tourism, its members, issues and operating forms is necessary to get more efficiency in decision processes, the allocating of resources and, consequently how the interests of the population are effectively represented in a participative and democratic political system.

In order to contribute to the debate on this issue, this paper aims to identify and analyze two moments in the political cycle, the process of perceiving a problem and the generation of proposals to be implemented by members of the Municipal Tourism Council of Juiz de Fora in Minas Gerais/Brazil over five years (2011-2015), from the analysis of the participation of actors in this social space. As key elements of such discussion, the participation of members is taken into account (frequency of meetings), as well as the degree of effectiveness of the proposals taken in the agendas (perception of a problem) and which have become results (implementation).

In addition to this introduction, the article presents four parts. In the second section, the theoretical framework on public management of tourism in Brazil and the public policies is placed as the basis of the research. In the third part, the methodology used for the analysis is outlined, the contributions of which are presented in the fourth section. Finally, in the last section, we consider the main conclusions and contributions reached in the study.

\section{Literature Review: Policy Analysis}

\section{Public Management of Tourism in Brazil}

In the recent trajectory of national tourism management, the experience of decentralized tourism management in the State of Minas Gerais, since 1999, stands out. This model was considered an innovation (Oliveira, 2014; Emmendoerfer, Silva, \& Lima, 2014), being even used as a standard to the national level planning, given its remarkable result, since the first mandate of the president Luís Inácio Lula da Silva, in 2003. It is remembered that, at the beginning of the referred presidential period, this action was incorporated simultaneously to the creation of the Ministry of Tourism (MTUR), giving emphasis to tourism development through regionalization (Emmendoerfer, Silva, \& Lima, 2014), besides the expansion of the National Tourism Council (CNT), which began to incorporate interests and civil society groups, previously not contemplated. Thus, a set of events considered a landmark in relation to the management of tourism activity is highlighted because from that moment on, the possibility of inserting the interests of civil society in spaces of democratic discussion was demonstrated, which could lead to influence the development of guidelines and actions for tourism activity in the country.

During this period, associated to the structural changes related to the traditional dynamic that occurs at the beginning of new governmental cycles, there were marked structural changes in tourism management, because there was a concern with the social development of the country, including themes such as ethics and sustainability. Thus, as a feature of the new public agenda, interests of groups that were not previously included in the tourism agenda, particularly organized civil society, were inserted (Chaves, 2011; Carvalho, 2015) ${ }^{5}$.

Within the context of encouraging the deconcentration of public functions and decentralized management of tourism public policies (Pimentel \& Pimentel, 2019), more specifically of the State of Minas Gerais, in 2006, the Tourist Circuits ${ }^{6}$ (CT's), considered as the public policy for the development of activity in the State (Oliveira, 2014), on their own initiative, created the Federation of Tourist Circuits of the State of Minas Gerais (FECITUR), with the objective of defending and representing the interests of the circuits, supporting representatives of private initiative and public power. It is worth noting, however, that, according to Oliveira (2014), the CT's, with its greater degree of decentralization and autonomy of local authorities, had an advance in local participation and consolidation of tourism

\footnotetext{
${ }^{5}$ The theme of characterization of the public agenda of tourism was exhaustively discussed by the literature. See, for example, Cavalcanti (2006), Araujo (2007). Chaves (2011), Carvalho (2014), Pimentel and Pimentel (2019), among others.

${ }^{6}$ The Tourist Circuits aimed to connect tourism destinations in regional sphere, to attract more tourists. In this way, they shelter a group of municipalities of the same region, with cultural, social and economic affinities that unite to organize and develop the regional tourist activity in a sustainable way, consolidating a regional identity. The work of these entities takes place through the continuous integration of municipalities, public managers, private initiative and civil society, consolidating a regional identity and leading the development through alliances and partnerships (SETUR, 2016a), access on 26 May 2016.
} 
networks in Minas Gerais, but had not yet achieved an advance with regard to regional development.

It should also be remembered that, as a way of stimulating this management model, in 2009 tourism was included in State Law $\mathrm{n}^{\circ}$. 18,0307, known as the Robin Hood Law, which provides for the distribution of the portion of revenue from the collection of the Tax on Operations Related to the Circulation of Goods and Services Rendered in Interstate and Intermunicipal Transport and Communication (ICMS), to the Municipalities of the State of Minas Gerais. Thus, tourism appears in Section I, Subsection VIII, as one of the criteria contemplated, since it is recognized as an instrument of the democratic income distribution, and allows all sectors of the economy a great benefit, promoting economic, social and cultural development (MG-SETUR, 2016b).

Thus, the core of this article is precisely the analysis during this event, since, in order to receive the resource from the ICMS tourism transfers, the municipalities of Minas Gerais should meet the following criteria: 1) participate in a Tourist Circuit (CT) recognized by SETUR; 2) have a municipal tourism policy prepared and in the process of implementation; 3) have a Municipal Tourism Council (COMTUR), constituted and in regular operation; and 4) have a Municipal Tourism Fund (FUMTUR) constituted and in regular operation (MG-SETUR, 2016b; Assis, 2014).

What was aimed thourght that public policy was to promote the articulation and professionalization of the sector at the local level. In this sense, it was an external contextual stimulus from the Ministry of Tourism (MTUR) and the State Secretariat of Tourism (MG-SETUR), as a consequence of the establishment of the Regionalization Policy in Brazil.

In this way, the financial incentive was used as a mechanism to stimulate the decentralized management of tourism, a strategy whose ultimate goal was to create alternatives for generating development at the municipal and regional levels through tourism activity.

The political system is made up of several actors who have different interests as well as different capacities to intervene in the decisions taken by the government in a given territory. Within this framework, interrelations are established between the participating actors - or those concerned with the various issues of public interest - with the aim of making policy, which has the function of "resolving conflicts between individuals and groups, without this conflict destroying one of the parties" (Schmitter, 1984, p. 36). This definition is directly related to the structuring of political arenas. The reasons for the existence of conflicts can be scarcity or need for resources, as well as power struggles. In this scope, politics is the process in which agents seek the resolution of problems through cooperation.

On the other hand, the State needs the means to support its decisions, manage public resources, and be accountable to the population, among other activities. Thus, policy analysis provides the support to examine the paths and trends characteristic of each period and each particular place, considering actors, resources, interests and external influences as some of the central elements, which together are capable of explaining the outcome of policy-related actions.

Among the various concepts associated with policy analysis present in the literature of political science, the following stand out: policy arena, policy network and policy cycle (Frey, 2000). These ones reflect processes of discussion, dispute over resources, positions and other existing relationships.

The policy arena is formed by the set of conflict and consensus processes within the various policy areas, which can be characterized by the objective of distributing resources to a large part of society, or the redistribution of resources destined for a specific purpose to meet another considered a priority; in addition to the normatization of the "rules of the game" through decrees, laws, ordinances, and the constitutive policies that define the conditions for defining regulatory, redistributive and distributive policies (Lowi, 1972).

In this way, from the analysis of policy networks, the interactions of the different institutions and groups involved in the political debate - both the executive, the legislative and the society - are differentiated and represented in order to explain the genesis and the dynamics of implementation of a given policy (Heclo, 1978).

On the other hand, in case a group of actors is not able to constitute itself around a sectorial policy as a whole (such as, for example, environment policy), even if they only identify common interests

${ }^{7}$ Available at $\langle$ http://www.turismo.mg.gov.br/images/stories/icmsturistico/lei-18030-2009.pdf > 
associated to some strictly delimited issues (such as the movement to implement a project of selective collection, waste recycling or the creation of an environmental protection area), the formation of issue networks is observed (Miller, 1994).

Finally, the concept of policy cycle represents a procedural understanding of the policy, through the definition of five phases: (1) perception of the problem, (2) agenda definition, (3) formulation of proposals (programs or projects) to solve the problem, (4) implementation and (5) evaluation. The perception of a problem involves the identification by the actors of the most appropriate issues for political treatment (Frey, 2000). Agenda setting is the process of deciding which issues will be the focus of government actions (Theodoulou, 1995). In the elaboration, programs or projects are established that are considered capable of solving the issues on the agenda. Implementation is the execution of the program by agents defined in its planning. Evaluation is the verification of compliance with the proposed objectives, usually based on previously defined indicators. Thus, the results of the evaluation can be used to adjust a policy or to close it.

Although we consider all the moments of the political cycle fundamental to the political analysis, in this work we will deal specifically with two moments: the process of perception of a problem and the concretization of the debates undertaken, through the implementation of concrete actions resulting from proposals that emerge in a space of social participation.

\section{Methodology}

This study is part of a broader research ${ }^{8}$ on the dynamics of organized collective action (Friedberg, 1992) in spaces of social participation, from which we extract a specific issue on participation for this text - here this concept is translated both in terms of its frequency of attendance at meetings, herein understood as "nominal participation" , and in terms of its proposals on the agenda, herein understood as "qualified participation"9 - of members who participate in a Municipal Tourism
Council of Juiz de Fora, in the State of Minas Gerais/Brazil, over the period of five years (20112015).

Therefore, in order to achieve the objective of analyzing and compare the moments of the political cycle of perception of a problem and the generation of proposals to be implemented, by members of the Municipal Tourism Council (COMTUR), it was sought to understand, in a specific case, the process of perception of a problem and the implementation of actions originated in proposing its solution, within a democratic space of participation. To this end, they were specifically analyzed:

1. The frequency of members, by means of two categories:

a) nominal participation (or frequency of attendance at meetings per entity): the participation of each entity per meeting in each year (2011-2015) was visualized, making it possible to observe the entities most present;

b) qualified participation: given by proactive action at meetings, manifested through speeches, engagement in debates and proposals for actions. These elements were preliminarily identified in minutes and subsequently cross-checked and validated with field diaries and information gathered in interviews and observation, participant and non-participant, conducted by members of the research.

2. Identification of the dynamics that takes place in the phases of the political cycle, through the:

c) perception of the problem: identification of the contents of the discussion agendas, exposed in the minutes of each of the meetings (i.e. how the themes are distributed throughout the year $)^{10}$; and the

d) implementation: when the identification of proposals that have become concrete actions was visualized, from the previous identification of which actions were executed.

3. Relationship between the frequency of the entities and the main themes of the agenda that became concrete actions:

In this last item, we sought to verify whether, in addition to nominal participation (i.e., that related only to presence or absence at meetings), there is any correlation between the participation of members, in terms of its more subjective and/or qualitative character, i.e., what is understood here as "qualified participation", which translates into the perception of a problem, and the actual implementation of actions, and, finally, the relationship between presence and discussion topics and the effectiveness of the proposals and results generated.

\footnotetext{
${ }^{8}$ In the survey, characterized by mixed (quanti-qualitative) methods, we have used different methods (survey, case study and clinical method) and procedures (questionnaire, interview, participant and non-participant systematic observation, and diary notes) which were made by different researchers. We have also used, the bibliog raphic and documentary material, thus seeking to achieve the best possible form of triangulation. For this paper, as a matter of space, we have focused on the mention of the quantitative and qualitative procedures, related only to the participation analysis.

${ }^{9}$ We can understand, from White (1996), that nominal participation is that in which it resembles passive participation and by consultation, which according to the author could be framed as non-participation. Although the content of our findings may be framed in this category, here we use the term nominal participation to refer to the simple act of being present, without engagement in dialogues, consultations or suggestions, that is, without an explicit manifestation or further engagement; which will be opposed by the type of qualified participation, that one where the right to speak will not only be exercised but will proactively give place to the manifestation of proposals, aiming at the solution of common problems.

${ }^{10}$ Here lays an underlying hypothesis: if there is some logic (explicit or hidden agenda) in the distribution of the subjects throughout the year or if they emerge randomly, according to contextual/emergency demands, and still if there is some dynamics/cycle of tendency to repeat the subjects (even if they emerge ad hoc, that is, in an unplanned way), so these questions would appear on the analysis.
} 
Methodologically, the techniques used were: documental analysis of laws and municipal ordinances related to COMTUR, as well as its Internal Regulations (see table 1).

Table 1: List of Documents and Laws Analyzed

\begin{tabular}{|l|l|}
\hline Documents & Theme \\
\hline $\begin{array}{l}\text { Law no. 12,178, of } \\
\text { December 16 }\end{array}$ & $\begin{array}{l}\text { Provides on the Municipal Council of Tourism and } \\
\text { the Municipal Tourism Fund }\end{array}$ \\
\hline FUMTUR Law & Chapter II of Law $12^{\text {th }}, 178$ \\
\hline $\begin{array}{l}\text { Ordinance 07.448, of } \\
\text { February 09 }\end{array}$ & $\begin{array}{l}\text { Appoints the representatives to the Municipal } \\
\text { Tourism Council }\end{array}$ \\
\hline $\begin{array}{l}\text { Law } \mathbf{n}^{\mathbf{0}} \mathbf{1 2 . 8 1 2} \text { of } \\
\text { June } \mathbf{1 2}^{\text {th }}, \mathbf{2 0 1 3}\end{array}$ & Amends Law No. 12,178, of December $16^{\text {th }}, 2010$ \\
\hline $\begin{array}{l}\text { Ordinance } \mathbf{n}^{\mathbf{0}} \mathbf{8 4 7 5}, \\
\text { of July 22 }\end{array}$ & $\begin{array}{l}\text { Appoints the representatives to the Municipal } \\
\text { Tourism Council }\end{array}$ \\
\hline $\begin{array}{l}\text { COMTUR Internal } \\
\text { Regiment }\end{array}$ & $\begin{array}{l}\text { Internal Rules established by the members of the } \\
\text { Municipal Council of Tourism of Juiz de Fora - } \\
\text { COMTURJF, as determined by Law No. 12,178, of } \\
\text { December } 16^{\text {th }}, 2010\end{array}$ \\
\hline $\begin{array}{l}\text { Law } \mathbf{n}^{\mathbf{0}} \mathbf{1 8 . 0 3 0}, \\
\text { January 12 }\end{array}$ & $\begin{array}{l}\text { Provides for the distribution of the revenue share of } \\
\text { the proceeds of ICMS collection to the } \\
\text { municipalities of the State of Minas Gerais. }\end{array}$ \\
\hline
\end{tabular}

Specifically, 66 meeting minutes were identified in the period of February 2011, date of its reactivation, and December 2015, the last available minutes in COMTUR's electronic website11 (Table 2). However, three minutes of the meetings -of 30 October 2013, 30 April 2014 and 1 December 2014were excluded because they were ordinary meetings of the Municipal Tourism Fund (FUMTUR) at which the expenditures of the FUMTUR were reported ${ }^{12}$.
Then, by means of the content analysis technique (Bardin, 1977), 63 minutes of meetings of the Municipal Tourism Council were analysed.

The analysis of the minutes of meetings made it possible to verify the frequency and the subjects on the agenda of the members. Thus, by identifying and comparing the presence of members in meetings it was observed the degree of participation of these actors $^{13}$ and their involvement in the discussion and proposals for actions. That was supposed to involve competition with the members of COMTUR/JF. Finally, through participant observation, it was sought to understand the political game that determines the results of the actions of the members who are part of the board. Thus, it was verified (1) how the council agenda of discussions is distributed throughout the year; (2) whether there is any logic (explicit or hidden) in the distribution of issues through the annual agenda; or whether a random emergence of issues prevails, according to contextual/emergency demands; and also, (3) whether there is some dynamic/trend cycle that leads to the repetition of issues (even if they emerge ad hoc, that is, in an unplanned way).

Table 2: Dates of the meeting analized (feb. $2011-$ dec. 2015).

\begin{tabular}{|c|c|c|c|c|c|}
\hline Month & 2011 & 2012 & 2013 & 2014 & 2015 \\
\hline January & - & Day $31-\mathrm{O}^{*}$ & Day $30-\mathrm{O}$ & Day $30-\mathrm{O}$ & Day $28-\mathrm{O}$ \\
\hline \multirow{4}{*}{ February } & Day $01-\mathrm{O}$ & \multirow{4}{*}{ Day $29-0$} & \multirow{4}{*}{ Day $28-O$} & \multirow{4}{*}{ Day $27-0$} & \multirow{4}{*}{ Day $27-O$} \\
\hline & Day $10-\mathrm{E}^{* *}$ & & & & \\
\hline & Day $10-\mathrm{O}$ & & & & \\
\hline & Day $16-E$ & & & & \\
\hline \multirow{2}{*}{ March } & \multirow{2}{*}{ Day $16-O$} & \multirow{2}{*}{ Day $29-\mathrm{O}$} & \multirow{2}{*}{ Day $26-O$} & Day $18-\mathrm{O}$ & \multirow{2}{*}{ Day $26-O$} \\
\hline & & & & Day $31-\mathrm{O}$ & \\
\hline \multirow[b]{2}{*}{ April } & \multirow[b]{2}{*}{ Day $13-\mathrm{O}$} & \multirow[b]{2}{*}{ Day $27-0$} & Day $04-\mathrm{O}$ & Day $25-\mathrm{O}$ & \multirow[b]{2}{*}{ Day $15-\mathrm{O}$} \\
\hline & & & Day $26-O$ & $\begin{array}{l}\text { Day } 30-\mathrm{O} \\
(\text { FUMTUR } * *)\end{array}$ & \\
\hline May & Day $24-\mathrm{O}$ & Day $30-\mathrm{O}$ & Day $29-\mathrm{O}$ & Day $30-\mathrm{O}$ & Day $20-\mathrm{O}$ \\
\hline June & Day $01-\mathrm{O}$ & Day $28-\mathrm{O}$ & Day $12-\mathrm{O}$ & Day $30-\mathrm{O}$ & Day $11-\mathrm{O}$ \\
\hline July & Day $29-\mathrm{O}$ & Day $31-\mathrm{O}$ & Day $31-\mathrm{O}$ & Day $31-\mathrm{O}$ & Day $23-\mathrm{O}$ \\
\hline August & Day $03-\mathrm{O}$ & Day $28-\mathrm{O}$ & Day $21-\mathrm{O}$ & Day $28-\mathrm{O}$ & Day 14- O \\
\hline September & Day $16-\mathrm{O}$ & Day $27-\mathrm{O}$ & - & Day $26-\mathrm{O}$ & Day $16-\mathrm{O}$ \\
\hline \multirow{2}{*}{ October } & \multirow{2}{*}{ Day $20-O$} & Day $11-\mathrm{E}$ & \multirow{2}{*}{$\begin{array}{l}\text { Day } 30-\mathrm{O} \\
(\text { FUMTUR } * * *)\end{array}$} & \multirow{2}{*}{ Day $30-\mathrm{O}$} & \multirow{2}{*}{ Day $27-0$} \\
\hline & & Day $18-\mathrm{O}$ & & & \\
\hline November & Day $01-\mathrm{O}$ & Day $29-\mathrm{O}$ & Day $28-\mathrm{O}$ & Day $26-\mathrm{O}$ & Day $27-\mathrm{O}$ \\
\hline \multirow{2}{*}{ December } & \multirow{2}{*}{ Day $14-\mathrm{O}$} & \multirow{2}{*}{ Day $19-0$} & \multirow{2}{*}{ Day $18-O$} & $\begin{array}{l}\text { Day } 01-\mathrm{O} \\
\text { (FUMTUR***) }\end{array}$ & \multirow{2}{*}{ Day $15-\mathrm{O}$} \\
\hline & & & & Day $17-\mathrm{O}$ & \\
\hline
\end{tabular}

Note: $* O$ - ordinary meeting; $* * E$ - Extra-ordinary meeting; $* * *$ Meetings whose issues weren't analysed.

Source: adapted from PJF (2016). Available in: 〈https://www.pif.mg.gov.br/conselhos/turismo/atas de reunioes.php〉. Access in: feb. 24.2016.

${ }^{11}$ This source was used due to its official and institutional character, being considered a legal document to measure the presence of members in meetings. They can be found on the official website of the city hall, dedicated to COMTUR. Available at: 〈https://www.pif.mg.gov.br/conselhos/turismo/atas_de_reunioes.php〉. Access in Feb. $24,2016$.

${ }^{12}$ The financial transfers made from other entities of the federation to the Municipality of Juiz de Fora are not necessarily used in the tourism sector, so they are directed to the single account of the municipal treasury. The transfers must pass through the municipal tourism fund (FUMTUR), as long as there is a note (or commitment) for the realization of authorized expenses by the municipal treasury. Thus, the effective behavior of the meetings (and, of course, of the records in minutes) of the FUMTUR are, in a way, only formal, since they only record and refers to expenditures authorized and carried out by the secretary of finance.

${ }^{13}$ Participation is a broad and widely discussed theme in the literature in its most diverse perspectives (as to the form: whether direct or indirect/representative; as to the object: whether political, economic, social (organized civil society), or organizational/productive, among others; or even in relation to the different types and degrees of participation that an actor can play. 


\section{Analysis}

The Municipal Tourism Council Board of Juiz de Fora The Municipal Tourism Council was reactivated and regulated through Law No. 12,178 of December 16th 2010, with the aim of contributing to the formulation of tourism policies, articulating the various actors linked to the sector in the city. Ordinance 07.448 of February 9th 2011 appointed the first councilors. Since then, COMTUR meetings are held periodically and without interruption each month, functioning as an advisory and inspection collegiate body, intended to guide, encourage and promote tourism in the Municipality. Its nongovernmental majority composition had the intention of establishing a social control character (Mata, Pimentel, \& Emmendoerfer, 2019). During the study period, COMTUR was linked to the Secretariat of Economic Development, Employment and Income.
It should be noted that the motivation to reactivate COMTUR was primarily and explicitly intended to meet the requirements of the National Tourism Plan 2011-2013 and the State Tourism Policy in course at that time, which linked the transfer of resources to municipalities from the ICMS tourism (on the ICMS tourism, see section "Public Management of Tourism in Brazil").

The internal regulations of COMTUR postulate that their members are responsible for participating in meetings, considering and voting on matters subject to evaluation. They must analyze technical opinions given by the members, provide information and data to assist in the decisions taken and forward matters to be discussed in the Plenary. In addition, they shall propose the creation of permanent and/or temporary technical committees to deal with matters of interest to the Board, as well as elect the

Table 3: Members of COMTUR from 2011-2015

\begin{tabular}{|c|c|}
\hline Period & Organization \\
\hline $\begin{array}{l}\text { July } 2013 \text { to March } \\
2015\end{array}$ & $\begin{array}{l}\text { Associação Profissional das Empresas de Transporte de Juiz de Fora e Zona da Mata - ASETRAP** (Professional } \\
\text { Association of Transport Companies of Juiz de Fora and Zona da Mata) } \\
\text { Associação Cultural e Recreativa Brasil-Alemanha - ACRBA (Cultural and Recreational Association Brazil-Germany) } \\
\text { Câmara de Dirigentes Lojistas - CDL (Chamber of Shopkeepers) } \\
\text { Federação das Indústrias do Estado de Minas Gerais - FIEMG (Federation of Industries of the State of Minas Gerais) } \\
\text { Serviço de Aprendizagem Comercial - SENAC (Commercial Learning Service) } \\
\text { Sindicato do Comércio de Juiz de Fora - SINDICOMERCIO (Trade Union of Juiz de Fora) } \\
\text { Sindicato dos Taxistas e Transportadores Autônomos de Passageiros de Juiz de Fora (Union of Taxi Drivers and } \\
\text { Autonomous Passenger Carriers of Juiz de Fora) } \\
\text { Sindicato dos Trabalhadores no Ramo de Motorista Auxiliar de Táxi Vans e Escolares - SINDITAXI AUXILIARES** (Union } \\
\text { of Workers in the Branch of Auxiliary Taxi Driver Vans and School) } \\
\text { Sociedade Nacional de Apoio Rodoviário e Turistico - SINART (National Society for Road and Tourism Support) } \\
\text { Centro de Ensino Superior de Juiz de Fora - CES JF (Higher Education Center of Juiz de Fora) } \\
\text { Faculdade Machado Sobrinho** (Machado Sobrinho Faculty) }\end{array}$ \\
\hline
\end{tabular}

Note: * Left out participating on July 2013. ** left out participating on April 2015.

Source: proper elaboration. 
Chairman, Vice-Chairman, Secretary and Directors from among the participants.

The Board is composed of public sector, entities that perform some function related to the planning and organization of tourism, and civil society and that act both in the areas of planning and in activities related to the provision of tourism services in the locality. The organizational structure is formed by an Executive Board (President, Vice-President, Secretary), Fiscal Committee and other Members (PJF, 2010), presented in Table 3.

The period under review corresponds to two managements. From 2011-2013, the first period of management, COMTUR was composed of 21 members $^{14}$, in accordance with Ordinance No. 7448 of February 9th, 2011, appointed in accordance with Law 12,178 of December 16th, 2010. Through Ordinance No. 8475 and Law No. 12,812 of July 12 th, 2013 , the second management, 2013-2015 15, began, in which the composition of the board was expanded. Specifically, 11 other entities were accepted and appointed ${ }^{16}$, however, during this period, 3 entities left, leaving, in total, 29 participating entities. In addition, in April 2015, 4 entities left and 3 others joined, totaling 28 participating entities from April to December 2015.

It is important to consider the total period examined in two managements, as it would be a way to identify traces of evolution and patterns in practices related to the dynamics of the Council. Considering the possibility of change both of the executive secretariat and of the councilors themselves in representing the entities, two main situations would arise: permanence contributes to the continuity of discussions and processes, such as rituals related to the dynamics of the meetings, and also supposes that there is accumulated knowledge about the tourist context of the municipality, and its role and tourist possibilities in a broader context in regional and national terms, as well as in relation to the actors involved in the local tourist sector that participate or not in the Council. On the other hand, the entry or exchange of members can favour the entry of new ideas and topics on the Council's agenda, as well as the insertion of new practices.

In this sense, a favorable situation would be the partial renewal of the Council in order to maintain the knowledge acquired over time, and to lead to the maturing of discussions and avoid a regression to what has been acquired so far. It is argued that these situations can be positive or negative, depending on other aspects that contribute to the shaping of the internal and external environment in which discussions take place.

\section{Attendance of Members in 2011-2015}

Specifically, this section aims to analyze the frequency of entities throughout the period studied, from 2011 to 2015 . It consists in verifying the presence and absence of the entities in ordinary and extraordinary meetings. The results represent the correlation between the presence/absence of members according to the total of meetings, year by year.

\section{Attendance to the Meetings}

The frequency of the members in the meetings is presented in Figure 1, whose focus was the visualization of the presence and absence of each member of the entity represented throughout the year. Thus, it can be seen that the number of absences was increasing during the period under review. Only the year 2011 had more attendances than absences. In the following four years, the

\section{E्EPresent 틀 Absent}

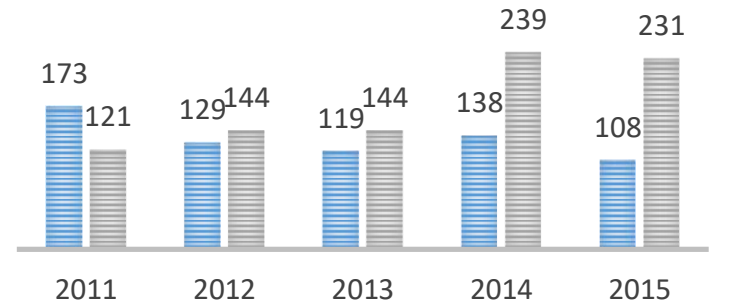

Figure 1. Attendance on the meetings on COMTUR (feb. 2011 dec. 2015)

Source: proper elaboration upon the data from COMTUR (2011-2015).

\footnotetext{
${ }^{14}$ The financial transfers made from other entities of the federation to the Municipality of Juiz de Fora are not necessarily used in the tourism sector, so they are directed to the single account of the municipal treasury. The transfers must pass through the municipal tourism fund (FUMTUR), as long as there is a note (or com-mitment) of commitment for the realization of authorized expenses by the municipal treasury. Thus, the effective behavior of the meetings (and, of course, of the records in minutes) of the FUMTUR are, in a way, only formal, since they only record and refers to expenditures authorized and carried out by the secretary of finance.

${ }^{15}$ In the period of 2013-2015 the management board was initially composed of Ditur/SDEER, in the presidency, ABAV, in the vice-presidency, and ABRASEL assumed the position of secretary of the board. ABAV was replaced by UFJF in the course of the term of vice-presidency. During this period, the Fiscal Council was composed by ACE-JF, SINDICOMÉRCIO, SINDITAXI AUXILIARES, SEBRAE and CTCN.

${ }^{16}$ As for the changes in entities, it should be noted that the Union of Hotels, Restaurants, Bars and Similar of Juiz de Fora - SHRBSJF and the Faculty Estácio de Sá/Tourism Course do not appear among the board members in the 2013-2015 management. On the other hand, the Union of Workers in the Branch of Auxiliary Taxi Vans and School Drivers - SINDITAXI AUXILIARES and Machado Sobrinho Faculty were inserted as members according to Ordinance No. 8475/2013. The case of SHRBSJF is particular because the entity is incorporated to the board in Ordinance 2011, but no longer participates, is excluded from COMTUR, and returns only at the end of management 20132015, according to Ordinance 2015 .
} 


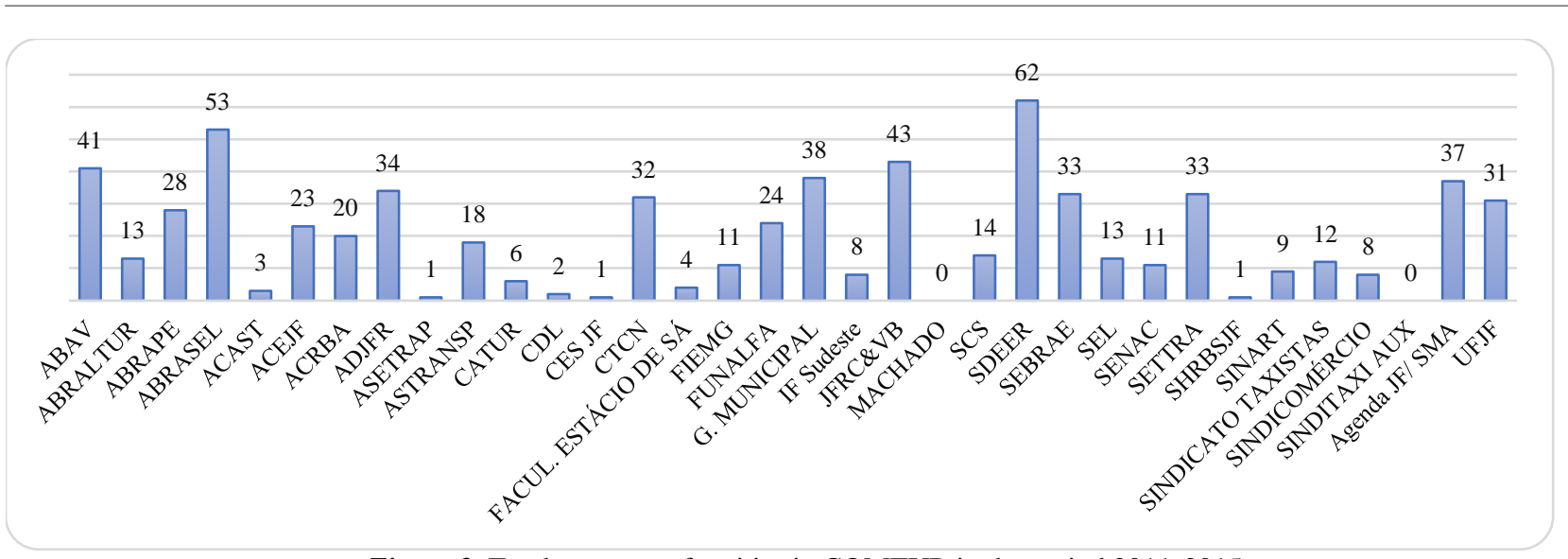

Figure 2. Total presence of entities in COMTUR in the period 2011-2015

Source: proper elaboration upon the data from COMTUR (2011-2015).

number of absences increased remarkably. In total, it was verified 667 attendances compared to 879 absences, which shows a lack of interest on the major part of the entities in participating in Council meetings. In general terms, half of the staff were not present at even $50 \%$ of the meetings during the whole period under review.

\section{Attendance to the Meetings per Entity}

The nominal participation is represented in Figure 2, in which was analyzed the frequency distribution of each participating entity per meeting during the entire period. It made possible to identify the entities most present on the meetings. It can be seen that the entities that participated most in COMTUR meetings in the period from 2011 to 2015 were Ditur/SDEER with 62 attendances, ABRASEL with 53 attendances and JFRC\&VB with 43 attendances. In general, the frequency of attendance to the meetings was low. Most members did not attend even half of the meetings held throughout the period under review. The entities that participate most are directly related to the private sector of tourism in Juiz de Fora.

Qualified Participation and Policy Intervention in the

$$
\text { Period 2011-2015 }
$$

In this section, the topics discussed at the meetings are highlighted, as well their proponents. The aim was to identify the issues that were put on the agenda or that arose during some discussion (perception of a problem), and then to filter those that became an alternative to be elaborate to guide a concrete action (implementation).

\section{Perception of the Problem}

According to Frey (2000), the perception of a problem involves the identification by agents of the most appropriate issues for political treatment. To represent how the themes are distributed throughout the year, the main problems perceived were related, the synthesis of the contents of the minutes of the meetings, by year, and the entities involved in these discussions.
In 2011, out of the 13 main themes discussed, only 4 were recurrent in the search for their conclusion: (1) the public call to support tourism projects, (2) diagnosis of tourist attractions from the city, (3) committees (work group to study specific issues on the Council] and (4) awareness campaign [driven to the residents]. Most of the issues that came out during the year were only cited and no longer mentioned, such as fundraising, event creation to raise funds and logo. ABAV and Ditur/SDEER were more present throughout 2011, followed by ABRAPE and ADJFR. It is important to highlight that, during this first year of council activities, the dynamics of work was organized through committees, the meetings were held on different days from ordinary and extraordinary meetings, so that only the results of these meetings were brought to the discussion agenda.

During the year of 2012, in all meetings, 17 main issues were addressed. From these, only 4 were debated more than once and had continuity: (1) creation of tourist information posts, (2) implementation of information posts, (3) totems of tourist information and (4) the public call to support financially tourist projects. In 2012, the institutions that participated most were ABAV, Ditur/SDEER, Guarda Municipal, Agenda JF, ADJFR and JFC\&VB, and the first two were present in all meetings.

During 2013, from the 10 issues addressed during all year long, those that appeared in at least more than one meeting were: (1) presentation of committee activities, (2) voting on the best option to solve problems with calls for proposals to support projects, and (3) amendment of the bylaws. The most present agents this year were Ditur/SDEER, ABAV, ABRASEL and SEBRAE. 
In 2014, from the 13 topics discussed during the year, only 4 were debated more than once and have had a continuity: (1) reallocation of dates of the call for proposals for support to projects, (2) call for proposals for support to tourism projects 2015, (3) commission for evaluation of tourism projects and (4) a tourism public seminar. It is worth to note that the first three topics were related to the call for proposals for support to tourism projects. Just the last one was different. The most present entities this year were Ditur/SDEER, ABRASEL, ACRBA, JFC\&VB, CTCN, FIEMG and SETTRA.

Among the 17 topics identified in the 2015 agenda, 8 were recurrent in the composition of the agendas: (1) online forum, (2) voting for the agreement of the project office, (3) call for proposals for support to tourism projects, (4) commission for election of new members of the executive board (next management), (5) presentation of projects of the Project Office, (6) maintenance of the call for proposals for support to projects for 2016, (7) presentation of the master plan, (8) presentation of guidelines for the master plan. ABRASEL, Ditur/SDEER, CATUR, ACRBA and UFJF were the institutions that were most present.

Elaboration of Proposals (and some Implementation) According to Theodoulou (1995), programs or projects that are established in the elaboration are considered capable of solving the issues on the agenda. Of all the discussions during the period 2011-2015, only a few became an alternative, formulated as a formal plan, and just some of that, were converted in concrete actions (proposals implemented), obtaining real results. Table 4 summarizes these data.
On the basis of the proposals that achieved concrete results, it was possible to trace the proposing entities of each of them and compare them with the type of participation. It should be noted that over the entire 5-year period (20112015), COMTUR was only able to obtain 7 concrete results. This is due to many generic discussions without concerning any real problem, with many ideas, but with no concrete proposals for action and division of tasks among the participants. Furthermore, a lack of commitment of the entities to the Council is perceived, as their frequencies are very low.

It is important to point out that, in addition to these topics mentioned there are many discussions around the regulations, rules and operation of COMTUR itself, as well as technical issues such as elections, deadlines, dates. This generates wide debates, using the time of the meetings to discuss and clear up doubts about something that should already be very well defined and known by all members.

Another very recurrent discussion is the need for greater presence of the entities in the meetings, besides improving its dynamics to transform the ideas/problems that are relevant to the organization of tourism in the municipality into concrete actions. The proposal and the need to remake the Municipal Tourism Plan is also a very recurring subject that does not generate concrete results. Since the reactivation of COMTUR until the last analyzed minutes, the Plan had not been elaborated, even running the risk of losing the transfer of funds from the ICMS tourism. Everyone has agreed that this was a mandatory and very

Table 4: COMTUR results in the period 2011-2015

\begin{tabular}{|c|c|c|}
\hline $\begin{array}{l}\text { Year of } \\
\text { Proposition }\end{array}$ & Proposal / Project & Proponent \\
\hline 2011 & Launch of the Project Support Notice & ABAV, Ditur/SDEER \\
\hline \multirow{2}{*}{2013} & Develop software to feed totem-shaped tourist information posts with touch screen technology & ABRASEL \\
\hline & Budget increase, seeking greater external fundraising & UFJF \\
\hline \multirow{2}{*}{2014} & $\begin{array}{l}\text { Discussion on the schedule created by the Commission for the Municipal Tourism Conference with } \\
\text { the objective of formulating the new Tourism Plan of Juiz de Fora. }\end{array}$ & $\begin{array}{l}\text { ABRASEL, JFRC\&VB, CTCN, } \\
\text { Ditur/SDEER } \\
\end{array}$ \\
\hline & $\begin{array}{l}\text { To seek, together with the councilors of the city council, in particular in its tourism commission, } \\
\text { parliamentary amendments to make the project office viable. }\end{array}$ & Ditur/SDEER, Abrasel, UFJF \\
\hline \multirow[t]{2}{*}{2015} & $\begin{array}{l}\text { Workshop given by the Sebrae governance consultant, when it was sought to define the roles of each } \\
\text { entity so that there is integration between the actors in the tourism production chain. }\end{array}$ & $\begin{array}{l}\text { Organizadores: Ditur/SDEER e } \\
\text { SEBRAE }\end{array}$ \\
\hline & Proposed guidelines for the Juiz de Fora Master Plan ${ }^{17}$ & Guarda Municipal, Ditur/SDEER \\
\hline
\end{tabular}

\footnotetext{
${ }^{17}$ Suggested topics: (1) Juiz de Fora's articulation with municipalities in the region, through Tourist Circuits, and approximation of state and federal government; (2) incentive to local commerce and services of interest to tourism and creation of stamps identifying the tourist establishments qualified; (3) including the creation of new areas to attract tourism-related investments, strengthening the city's position as an events hub, expanding the infrastructure and exhibition and cong ress spaces, creating conditions for appropriate kind of tourism according to the characteristics of the Municipality - of events, business, culture, gastronomy, shopping and agro and ecotourism - to increase visitor permanence; (4) granting tax benefits to service tax paying establishments (ISSQN, IPTU exemption, exemption from municipal taxes for installation and operation, simplification of procedures for installation and operation and obtaining permits and licenses - regulated by specific laws); (5) creating strategic poles, identifying and exploring the potential of each region of the municipality, creating sector identities: (6) promoting sites with tourist potential and environmentally sustainable; (7) ensuring tourist information in the tourist receiving units - airport, bus station, porticos, shopping malls, among others; (8) encouraging rural tourism and products with local identity; (9) rehabilitation of public spaces through security programs, preservation and urban recovery for tourist sites.
} 
important task. However, surprisingly, no one effort could push it forward. Despite the recurrent suggestions of some few actors - like UFJF -, probably due to the difficult of the task, no one has undertaking this individually.

\section{Relationship Among Nominal Participation, Effective}

\section{Participation and Factual Results}

In this last item, we sought to verify whether, in addition to nominal participation (i.e., that relating only to attendance or absence at meetings), there is any difference in relation to the participation of members in terms of its more substantive character, i.e., what is understood here as "qualified participation", which translates into the perception of a problem and its actual implementation. And, finally, the relationship between the frequency, the kind of participation and the proposals that effectively turned into concrete results.

Table 5 : Correlates the proposals converted into results according to the frequency of members.

\begin{tabular}{|l|l|l|}
\hline Entity & $\begin{array}{l}\text { Number of proposals } \\
\text { converted into results }\end{array}$ & $\begin{array}{l}\text { Total frequency } \\
(\mathbf{2 0 1 1 - 2 0 1 5 )}\end{array}$ \\
\hline 1-Ditur/SDEER & 5 & 62 \\
\hline 2-ABRASEL & 3 & 53 \\
\hline 3- UFJF & 2 & 31 \\
\hline 4-ABAV & 1 & 41 \\
\hline 5-SEBRAE & 1 & 33 \\
\hline 6-Guarda Municipal & 1 & 38 \\
\hline 7-JFRC\&VB & 1 & 43 \\
\hline 8-CTCN & 1 & 32 \\
\hline \multicolumn{2}{|l|}{ Source: proper elaboration upon the data from COMTUR (2011-2015). }
\end{tabular}

From this analysis, it was possible to observe that few proposals that emerged in COMTUR resulted in the implementation of effective actions. In this context, the proposals that COMTUR was able to elaborate and, some of then, be implement, are related to the 8 entities that were most frequent in the meetings.

Thus, it was possible to evidence that there is a correlation between the qualified participation of the members of the Council and their capacity to insert and maintain themes on the agenda of the Council. In this way, the problems perceived by such entities and placed on the agenda had greater possibility of resulting in the implementation of actions. On the other hand, it was identified that some of the entities that sporadically attend the meetings also sought to raise issues of their interest in the debates and get involved in the discussions of the agenda of the day. However, to mobilize and convince the other members about the relevance of their issues.

\section{Concluding Remarks}

This paper aimed to identify and analyze two moments in the political cycle: the process of perceiving a problem and the implementation (concrete actions/results) of proposals made by members of the Municipal Tourism Council of a city in Minas Gerais/Brazil over the five-year period (2011-2015).

COMTUR was reactivated in February 2011 with the explicit intention of meeting the requirements of the National Tourism Plan and the State Tourism Policy, which links the transfer of resources to municipalities to the existence of a Municipal Tourism Council and a Municipal Tourism Fund demonstrably active.

Regarding the idealized and realized proposals, we find that UFJF, ABRASEL and Ditur/SDEER are the entities that have the most proposals executed, since they are the actors who most conduct the debates and get their issues to be kept on the agenda. In other words, these entities have the greatest influence and guide the local tourist context according to their perceptions. These entities are even the only well-defined group, in the sense of presenting a homogeneous discourse and that, repeatedly, present the need for articulation and cohesion so that COMTUR is an organ capable of supporting the development of the tourism sector in an organized and planned manner. The other actors often seek to take up the themes of their interest and get little involved in the discussion of other themes.

Moreover, the evidence points to a direct relationship between the degree of participation in the meetings and the tendency to approve and implement the proposals made. Thus, it is clear that the direct relationship that exists between the entities with greater frequency in the meetings and the proposals actually executed.

In conclusion, despite a supposed openness in terms of the possibility of action, demonstration and participation in democratic contexts and spaces such as municipal councils, it is identified that the entities use COMTUR to put their interests into practice. Thus, COMTUR is used mostly in an instrumental way. In this way, the

\footnotetext{
${ }^{18}$ More than one entity proposed what was accomplished.
} 
the space of the Council does not fulfill its original function.

Moreover, an institutional weakness and a crisis of legitimacy of the Council was observed as a mechanism of participation, since most representatives of the interests of the tourism sector often do not use this space to contribute and interfere in the debates and actions related to tourism. Thus, due to the absence of obstacles and/or counterweights, there is a strong risk of opportunistic co-optation of this space by the most participative entities, which have the opportunity to impose their demands in a more incisive manner. An example of this is the distortion of municipal public tourism policy, which has been reduced to a more or less harmonious distribution of public resources available to the private sector, under the pretext of supporting the development of events to increase the flow of tourism in the city.

In this respect, as well summarized by Oliveira, Pereira and Oliveira (2010, p. 334 - free translation):

\begin{abstract}
In management councils, the risk of managerial participation taking precedence over political participation exists, especially when it is involved to: a) councilors who do not have strong links with social organizations; b) social organizations that relate tangentially to popular movements; c) popular movements that do not have historical or community ballast; d) local powers that act strategically not to share power; e) local powers do not consider councils legitimate or relevant; f) councilors who are unaware of social policy systems, the public machinery and the means to make their decisions viable; and g) processes of 'empowerment' of councilors are neglected.
\end{abstract}

In this sense, a promising new field of study may be that in which one seeks to rescue personal elements of the counsellors themselves - such as, for example, their socio-demographic profile and personal skills and attitudes - as well as the situational elements of the decision-making process, present in the interactive dynamics of the councils, in addition to deepening the broader institutional mechanisms that frame the possibilities of action. Another possibility, no less interesting, would be to reinterpret the issue in the light of new theories such as Civil Sphere Theory (Alexander, 2007).

\section{References}

Abramovay, R. (2001). Conselhos além dos limites. Estudos avançados, 15(43), 121-140.

Alexander, J. (2007). On the Interpretation of the Civil Sphere: Understanding and Contention in Contemporary Social Science. The Sociological Quarterly, 48(4), 641-659.

Almeida, D. R. de. (2009). Os Conselhos Municipais e sua estrutura normativa e institucional. In: Avritzer, L. et al. Democracia, Desigualdade e Políticas no
Brasil. Relatório de pesquisa do projeto democracia participativa, Belo Horizonte: FINEP, v. 2,2009 .

Araújo, C. R. M. (2007). A participação societal na concepção das políticas públicas de turismo no Brasil: o caso do Conselho Municipal de Turismo de São Paulo no período de 1991 a 2006. Tese (Doutorado) - Fundação Getúlio Vargas - Escola de Administração de Empresas de São Paulo, São Paulo.

Araujo, C. R. M. (2014). Civil Society Participation in Public Policy Processes in Brazilian Tourism: The Itupararanga-Sorocabana Touristic Region Forum. Anais Brasileiros De Estudos Turísticos $A B E T$, UFJF, v. v.4, p. P.8-P.14.

Araujo, C. R. M.; Cesar, P. A. B. (2012). Dimensão político-institucional do turismo no Brasil. In: Mário Carlos Beni. (Org.). Turismo: planejamento estratégico e capacidade de gestão. Barueri, São Paulo: Manole Ltda., v. 1, p. 257-282.

Assis, N. S. M. (2014). A Política de Regionalização do Turismo de Minas Gerais: um estudo de caso do Circuito Turístico Caminhos do Sul de Minas. Dissertação (Mestrado) - Universidade Federal de Minas Gerais. Belo Horizonte, Minas Gerais.

Augustyn, M. M., Knowles, T. (2000). Performance of tourism partnerships: a focus on York. Tourism Management, Volume 21, Issue 4, 341-351. https://doi.org/10.1016/S0261-5177(99)00068-0

Bardin, L. (1977). Análise do conteúdo. Lisboa: Edições 70.

Beaumont, N. \& Dredge, D. (2010). Local tourism governance: a comparison of three network approaches. Journal of Sustainable Tourism, Volume 1(18), 7-28. https://doi.org/10.1080/09669580903215139

Bobbio, N.; Matteuci, N.; \& Pasquino, G. (2004). Dicionário de política. Brasília: UnB.

Bourdieu, P. (2004). From the King's House to the Reason of State: A Model of the Genesis of the Bureaucratic Field. Constellations, 11(1), 16-36.

Brasil (1988). Constituição da República Federativa do Brasil de 1988. Presidência da República. Available http://www.planalto.gov.br/ccivil 03/constituicao/consti $\underline{\text { tuicao.htm }}$

Carvalho, F. C. C. (2014). Agenda pública do turismo no Brasil: mudanças e implicações para o desenvolvimento do turismo nacional. (Master tesis). 135f. - Escola de Governo Professor Paulo Neves de Carvalho/Fundação João Pinheiro. Belo Horizonte, Brazil.

Carvalho, F. C. C. (2015). Agenda Governamental e Trajetória Institucional do Turismo no Brasil. 
Revista Anais Brasileiros de Estudos Turísticos $A B E T$, Juiz de Fora (Brasil), 5(1), 59-70.

Cavalcanti, P. A. B. (2006). Um Olhar Crítico sobre o Conselho Nacional de Turismo: Articulação do Setor, Legitimidade e Auto-Interesse na Construção das Políticas Públicas. $143 \mathrm{f}$. Dissertação (Mestrado) - Escola de Administração de Empresas de São Paulo: São Paulo.

Chaves, M. P. A (2011). Institucionalização das Políticas Públicas de Turismo em Âmbito Municipal no Brasil. 287 f. Dissertação (Mestrado) Universidade Federal de Lavras (UFLA). Lavras, Minas Gerais.

Dredge, D. (2006). Policy networks and the local organisation of tourism. Tourism Management. Volume 27, Issue 2, 269-280. https://doi.org/10.1016/j.tourman.2004.10.003

Emmendoerfer, M. L.; Silva, F. C.; \& Lima, A. A. T. F. C. (2014). Inovação social na gestão pública do turismo: uma análise dos circuitos turísticos em Minas Gerais. In: Pimentel, T. D.; Emmendoerfer, M. L.; Tomazzoni, E. L. (Org.). Gestão Pública do Turismo no Brasil? Teorias, Metodologias e Aplicações. Vol. 1. 1. ed. Caxias do Sul - RS: EDUCS.

Frade Da Mata, G. M.; Emmendoerfer, M. L. (2017). Igualdade Participativa e Políticas Públicas: o caso de conselhos gestores de turismo de Ouro Preto e Tiradentes, Minas Gerais, Brasil. Anais Brasileiros de Estudos Turísticos: ABET, Vol.7(1), pp.103-114.

Frey, K. (2000). Políticas públicas: um debate conceitual e reflexões referentes à prática da análise de políticas públicas no brasil. Planejamento $e$ políticas públicas, 21.

Friedberg, E. (1992). Les quatre dimensions de l'action organisée. Revue Française de Sociologie, 33(4).

Gonh, M. G. (2011). Movimentos sociais na contemporaneidade. Revista Brasileira de Educação, 16(47), 333-363.

Gurgel, C.; \& Justen, A. (2013). Controle social e políticas públicas: a experiência dos Conselhos Gestores. Rev. Adm. Pública, Rio de Janeiro, 47(2), 357-378. Available $<$ http://www.scielo.br/scielo.php?script=sci_arttext \&pid=S0034-

$76122013000200004 \& \operatorname{lng}=\mathrm{en} \& n r m=\mathrm{iso}>$. Access in: 21 aug. 2018.

Heclo, H. (1978). Issue Networks and the Executive Establishment. In A. King (Hrsg.). The New American Political System. Washington D.C. American Enterprise Institute.

Instituto de Pesquisa Aplicada - Ipea (2012). O Conselho Nacional de Turismo na Visão de seus
Conselheiros. Relatório de Pesquisa: Projeto Conselhos Nacionais: perfil e atuação dos conselheiros. Governo Federal. Brasilia.

Kliksberg, B. (1999) Seis tesis no convencionales sobre participación. Revista de Estudios Sociales. Access in: 14jan2019]. Available in:<http://www.redalyc.org/articulo.oa?id=815112 66010> ISSN 0123-885X.

Lowi, T. (1972). Four Systems of Policy, Politics, and Choice. Public Administration Review, (32), 298310 .

Martins, S.; Ckagnazaroff, I. B.; Lage; M. L. da C. (2012). Análise dos Conselhos Gestores de Políticas Públicas à luz dos Relatórios de Fiscalização da Controladoria Geral da União. Administração Pública e Gestão Social, 2(4), 221-245

Massukado-Nakatani, M. S., \& Teixeira, R. M. (2009). Resource-based view as a perspective for public tourism management research: evidence from two Brazilian tourism destinations. BAR - Brazilian Administration Review, 6(1), 62-77. https://dx.doi.org/10.1590/S180776922009000100006

Mata, G. M. F. (2016). Conselhos Gestores como Mecanismos de Controle: Uma Análise em Destinos Turísticos (Master dissertation). Universidade Federal de Viçosa. Viçosa, MG.

Mata, G. M. F.; Pimentel, T. D.; \& Emmendoerfer, M. L. (2019). Policy Arena, Policy Network e Teoria de Campo Social no estudo da Gestão Pública de Turismo. Caderno Virtual De Turismo (UFRJ), Rio de Janeiro (Brasil), 19, 1-21.

Miller. P. (2009). Les politiques publiques. Collection : Que sais-je ?. Éditeur: Presses Universitaires de France. 128p.

Nóbrega, W. R. M. \& Figueiredo, S. J. L. (2014). Turismo e Gestão Pública: uma Avaliação das Instâncias de Governança no Oeste do Estado do Pará. In Pimentel; T. D.; Emmendoerfer; M. L.; \& Tomazzoni; E. L. (Orgs.). (Org.). Gestão Pública do Turismo no Brasil? Teorias, Metodologias e Aplicações. 1ed.Caxias do Sul - RS: EDUCS, 1, 360-396.

Oliveira, R. A. (2014). Descentralização: um paralelo entre os circuitos turísticos de Minas Gerais e o modelo francês de regionalização do turismo. In: Pimentel, T. D.; Emmendoerfer, M. L.; Tomazzoni, E. L. (Org.). Gestão Pública do Turismo no Brasil? Teorias, Metodologias e Aplicações. Vol. 1. 1. ed. Caxias do Sul - RS: EDUCS.

Oliveira, V. C. Da S; Pereira, J. R.; \& Oliveira, V. A. R. De. (2010). Os conselhos gestores municipais como instrumentos da democracia deliberativa no Brasil. Cad. EBAPE.BR, Rio de Janeiro, 8(3), 422-437, set. Available 
$<$ http://www.scielo.br/scielo.php?script=sci_arttext \&pid=S1679$39512010000300004 \& \operatorname{lng}=$ en\&nrm $=$ iso $>$. Access $: 21$ aug. 2018.

Oliveira, V. C. da S. (2009). Sociedade, Estado e administração pública: análise da configuração institucional dos conselhos gestores do município de Lavras - MG. Tese (Doutorado em Administração) Universidade Federal de Lavras, UFLA, Brasil.

Paddison, B. \& Walmsley, A. (2018). New Public Management in tourism: a case study of York. Journal of Sustainable Tourism, 6(26). https://doi.org/10.1080/09669582.2018.1425696

Paes de Paula, A. P. (2008). Por uma Nova Gestão Pública. Rio de Janeiro: Editora FGV.

Pimentel, M. P. C.; \& Pimentel, T. D. (2019). Avaliação política da política de estado de turismo de Minas Gerais. Revista Acadêmica Observatório de Inovação do Turismo, Rio de Janeiro (Brasil), 13, 131-157.

Pimentel, T. D.; Carvalho, F. C. C.; Oliveira, M. C. B.; Moura, E.F.L. (2019). Entre a Formalidade e a Efetividade: a dinâmica da participação social no ciclo político de um conselho gestor de turismo em Juiz de Fora/MG. RIGS - Revista Interdisciplinar de Gestão Social, Salvador (Brasil), 8, p. 117-142.

PJF - PREFEITURA MUNICIPAL DE JUIZ DE FORA (2010). Lei $n^{o} 12.178$, de 16 de dezembro de 2010. Diário Oficial Eletrônico. Prefeitura Municipal de Juiz de Fora, Juiz de Fora (2010). Available in: $<$ http://www.jflegis.pif.mg.gov.br/c_norma.php?chave $=0$ 000033403>. Access in: 01 apr. 2016

Schmitter, P. (1984). Reflexões sobre o Conceito de Política. In Curso de Introdução à Ciência Política: Política e Ciência Política (2a ed.) Brasília: UNB.

SECTUR/MG - Secretaria de Turismo de Minas Gerais (2016b). ICMS Turístico. Available at: $<$ http://www.turismo.mg.gov.br/icms-turistico>. Access in: 23 jun. 2016.

SECTUR/MG - Secretaria de Turismo de Minas Gerais. (2016a). Circuitos Turísticos. Available at: http://www.turismo.mg.gov.br/circuitosturisticos/informacoes-administrativas. Access in: 29 abr. 2016.

Tatagiba, L. (2005). Conselhos gestores de políticas públicas e democracia participativa: aprofundando o debate. Revista de Sociologia e Política, 25, 209-213.

Tenório, F. G. (2008). (Re)Visitando o Conceito de Gestão Social. In: Silva JR., Jeová T.; Mâsih, Rogério T.; Cançado, Airton C.; Schommer, Paula C. Gestão Social: práticas em debate, teorias em construção. $1^{\text {a }}$ Ed. Vol 1. Fortaleza: Imprensa Universitária, 248p. Cap. 2, p.39-60.
Theodoulou, S. Z. (1995). The Contemporary Language of Public Policy: A Starting Point. In S. Z. Theodoulou, \&, M. A. Cahn (Orgs.). Public Policy: The Essential Readings. New Jersey: Prentice Hall.

Velasco, M. (2016). Entre el poder y la racionalidad: gobierno del turismo, política turística, planificación turística y gestión pública del turismo. Pasos, 3(14), 577-594. doi.org/10.25145/j.pasos.2016.14.038

White, S. C. (1996). Depoliticising development: the uses and abuses of participation. Development in Pratice, 6(1), 6-15.

Zapata, M. J. \& Hall, C. M. (2012). Public-private collaboration in the tourism sector: balancing legitimacy and effectiveness in local tourism partnerships. The Spanish case. Journal of Policy Research in Tourism, Leisure and Events, 1(4), 61-83. doi.org/10.1080/19407963.2011.634069 